УДК 025.5-057.875:004.775:[026:37](477.411)

DOI:

Інна Агалець, кандидат педагогічних наук, доцент, старший науковий співробітник відділу наукового інформаційно-аналітичного супроводу освіти Державної науково-педагогічної бібліотеки Украӥни імені В. О. Сухомлинського НАПН Украӥни

\title{
НАУКОВО-ІНФОРМАЦЙНИЙ СУПРОВІД ДОСЛІДНИЦЬКОЇ ДІЯЛЬНОСТІ СТУДЕНТСЬКОЇ МОЛОДІ ЗАСОБАМИ НАУКОВОЇ БІБЛІОТЕКИ ПЕДАГОГІЧНОГО ПРОФІЛЮ
}

У статті розглянуто особливості використання науково-інформаційних ресурсів вебпорталу ДНПБ Украйни ім. В. О. Сухомлинського у здійсненні дослідницької діяльності студентською молоддю в умовах викликів світової пандемії Covid-19. Представлено низку документів науково-інформаційного супроводу освітянської галузі на порталі бібліотеки. Звернуто увагу на сферу застосування вторинної інформації. Запропоновано алгоритм “кроків” у пошуку та обранні ефективних иляхів оптимізачії науковоінформаційного супроводу дослідницької діяльності студентської молоді засобами наукової бібліотеки педагогічного профілю.

Сформульовано висновки: використання розробленого у ДНПБ Украӥни ім. В. О. Сухомлинського вторинного документного масиву як комунікаиійного інструменту супроводу наукової інформаційно-освітньої діяльності створює оптимальні умови для формування та розвитку у студентської молоді когнітивних вмінь, навичок та мотивації до наукової діяльності.

Ключові слова: науково-інформачійний супровід; дослідницька діяльність; вторинні науковоінформачійні документи; студентська молодь; освітянська галузь.

Jim. 8.

Inna Ahalets, Ph.D. (Pedagogy), Associate Professor, Senior Researcher of the Scientific Information and Analytical Support of Education Department of the Vasyl Sukhomlynskiy State Scientific and Pedagogical Library of Ukraine National Academy of Pedagogical Science of Ukraine

\section{THE STUDENT YOUTH RESEARCH ACTIVITY SCIENTIFIC AND INFORMATION SUPPORT BYTHE PEDAGOGICAL PROFILE SCIENTIFIC LIBRARY MEANS}

The article discusses the features the State Scientific and Pedagogical Library of Ukraine named after $V$. Sukhomlynskiy scientific and information resources web-portal use in research activities implementation by student youth in the global Covid-19 pandemic challenges context. The attention is focused on the professional information content students' orientation for scientific and educational goals achieve. Scientific support is projected, which optimizes the advantages of the students' scientific activity with the help of secondary scientific and information documents created in the library. It's argued that cognitive interest as significant link motivates young students to educational process, encourages activation and ensures cognitive activity high productivity, contributes to professional competencies acquisition. It's noted that State Scientific and Pedagogical Library of Ukraine named after $V$. Sukhomlynskiy, as a scientific institution, one of activity priority directions in Ukraine education and science is scientific and information support. The secondary documents system formation is justified, which on the State Scientific and Pedagogical Library of Ukraine named after V. Sukhomlynskiy portal and the National Academy of Pedagogical Sciences of Ukraine Electronic Library are constantly replenished and popularized. The article provided the information regarding understanding of primary and secondary documents ratio, the leading features and secondary documents examples. A number of documents on scientific and information support of the educational industry are presented on the library's web portal. An attention is drawn to the scale of secondary information. To find and select effective ways of scientific and information support for the optimization of research activities of young students in the scientific library of pedagogical profile, an algorithm of several "steps" is proposed.

Conclusions are formulated: using the scientific information and educational activities support secondary documentary tool, developed in the State Scientific and Pedagogical Library of Ukraine named after V. Sukhomlynskiy, creates optimal conditions for students' cognitive skills, skills and motivation for scientific activity formation and development.

Keywords: scientific and informational support; research activities; scientific and informational secondary documents; student youth; educational industry.

остановка проблеми. XXI ст. стало періодом входження України та багатьох країн світу в інформаційне

(C)

I. Агалець, 2021 суспільство, що передбачає подальший розвиток і використання нових інформаційно-комунікаційних технологій та засобів в усіх галузях 


\section{НАУКОВО-ІНФОРМАЦЙНИЙ СУПРОВІДДОСЛІДНИЦЬОӦ ДІЯЛЬНОСТІ СТУДЕНТСЬКОЇ МОЛОДІ}

ЗАСОБАМИ НАУКОВОЇ БІБЛІОТЕКИ ПЕДАГОГІЧНОГОПРОФІЛЮ

життєдіяльності, основою яких є наука, освіта і практика.

Зважаючи на те, що суспільству довелося прийняти виклик світової пандемії Covid-19, яка зумовила нові реалії життедіяльності, - навчитися жити, працювати й здобувати освіту за нових умов, варто особливу увагу, на наш погляд, приділити молоді, що нині навчається й в недалекому майбутньому здійснюватиме свої професійні обов'язки. У цьому контексті перед вченими й практиками освітянської галузі постає завдання перманентного наукового супроводу дослідницької діяльності студентської молоді науково-інформаційними документами. Одним зі шляхів розв'язання зазначеного завдання $\epsilon$ оптимізація можливостей дистанційного доступу до інформаційних науково-освітніх ресурсів.

Аналіз останніх досліджень і публікацій свідчить, що останнім часом зростає інтерес наукової та освітянської спільноти до проблеми науково-інформаційного супроводу розвитку освітньої галузі в нашій країні. Різні аспекти теоретико-прикладних наукових розвідок гуманітарної сфери та освітянської підсистеми держави стосовно питань, пов'язаних 3 використанням інформаційно-комунікаційних форм, методів та технологій у сфері бібліотечного забезпечення користувачів, висвітлено у працях багатьох учених й фахівців з бібліотечної справи (Л. Березівська, Л. Бондар, Т. Букшина, В. Горовий, Т. Гранчак, Т. Добко, І. Коваленко, В. Кремень, І. Лобановська, К. Лобузіна, В. Луговий, Л. Лутовинова, Л. Пономаренко, Л. Самчук, А. Селецький, Г.ШвецоваВодка, О. Яценко) та ін.

Останнім часом також опубліковано низку наукових праць, пов'язаних з проблемою інформатизації освітнього середовища в Україні, зокрема забезпечення підготовки студентства до професійної діяльності із використанням засобів і технологій дистанційного навчання (В. Биков, А. Гуржій, М. Жалдак, Т. Коваль, А. Кудін, В. Лапінський, Н. Морзе, С. Раков, Ю. Рамський, Н. Сиротенко, О. Спірін, Л. Шевчук та ін.), що сприяло створенню наукових та організаційнометодичних умов впровадження дистанційного навчання в освітній процес закладів освіти.

Мета роботи - спроба аналізу досвіду Державної науково-педагогічної бібліотеки України імені В. О. Сухомлинського (далі - ДНПБ України ім. В. О. Сухомлинського) щодо пошуку та обрання ефективних шляхів оптимізації супроводу дослідницької діяльності студентської молоді вторинними науково-інформаційними документами засобами наукової бібліотеки педагогічного профілю.
Виклад основного матеріалу. Поряд 3 освітянами Міністерства освіти і науки України (далі - МОН України) вагомий доробок науковоосвітніх джерел 3 питань освіти, педагогіки і психології створюють науковці Національної академії педагогічних наук України (далі - НАПН України). Такий доробок містить низку сучасних наукових, навчальних, навчально-методичних праць, в яких відображено результати застосування сучасних технологій, інноваційних методик, рекомендацій тощо, тобто первинні повнотекстові документи, що є основними серед галузевого інформаційного ресурсу України.

Обсяг надходження повнотекстових джерел нині істотно зростає. Тож перед сучасним студентством постає питання орієнтації в інформаційному потоці для досягнення науковоосвітньої мети у непростих умовах сьогодення, розв'язання якого забезпечуватиме переваги щодо оптимізації наукового супроводу дослідницької діяльності вторинними науковоінформаційними документами, створеними в науково-педагогічній бібліотеці.

Це, зокрема:

- уможливлює системний розвиток науковоінформаційного супроводу освітянської галузі;

- дає змогу залучити студентську молодь до аналітичної роботи, що сприяє активізації розумової діяльності;

- сприяє зменшенню як часових, так й інтелектуальних витрат студентської молоді у дослідницькій освітньо-науковій діяльності 3 пошуку, збирання й опрацювання джерельної бази;

- забезпечує підвищення рівня сформованості інформаційно-комунікаційної компетентності (ІКкомпетентності), що передбачає здатність особистості застосовувати сучасні комунікаційні технології та сприяє організації освітньо-наукового процесу на відстані й у зручному режимі (індивідуальність навчання).

Зважаючи на те, що студентський вік, як правило, становить від 17 до 25 років, й спираючись на результати досліджень фахівців 3 педагогіки і психології (І. Бех, В. Бондар, Н. Гузій, 3. Курлянд, Т. Осипова, Н. Павлова, О. Савченко, 3. Слєпкань, О. Шевнюк та ін.) та власний науково-педагогічний досвід, можна стверджувати, що молодь у цьому віці досягає найвищого рівня розвитку і сприйняття інформації. Саме в цей період відбувається активне формування життєвих позицій, становлення ціннісних орієнтацій у соціопрофесійній життєдіяльності. Важливою ланкою, що мотивує студентську молодь до освітнього процесу, є пізнавальний інтерес, який спонукає до активізації й забезпечує високу 


\section{НАУКОВО-ІНФОРМАЦЙНИЙ СУПРОВІДДОСЛІДНИЦЬКОЇ ДІЯЛЬНОСТІ СТУДЕНТСЬКОЇ МОЛОДІ ЗАСОБАМИ НАУКОВОЇ БІБЛІОТЕКИ ПЕДАГОГІЧНОГОПРОФІЛЮ}

продуктивність пізнавальної діяльності, сприяє набуттю професійних компетентностей.

“Передумовами виникнення у студентської молоді інтересу до процесу здобування фахових знань та засвоєння способів діяльності є: емоційна привабливість діяльності та їі результатів, максимальне залучення до пошукової діяльності, спрямованість уваги на потребу проведення дослідницької роботи, розкриття власних здібностей та нахилів" $[1,11]$.

Як відомо, галузевий інформаційний ресурс сфери освіти, педагогіки, психології формує мережа освітянських бібліотек МОН України та НАПН України, яку очолює ДНПБ України імені В. О. Сухомлинського як наукова інформаційна установа загальнодержавного рівня.

Одним із пріоритетних напрямів діяльності ДНПБ України ім. В. О. Сухомлинського $є$ науково-інформаційне забезпечення сфери освіти та науки України. Відповідно до цього формується система вторинних документів, до яких належать науково-інформаційні документи, що постійно поповнюються та оприлюднюються в ресурсах офіційного вебпорталу ДНПБ України ім. В. О. Сухомлинського та Електронній бібліотеці НАПН України.

У контексті теми статті має сенс зупинитися на відомостях щодо розуміння співвідношення первинних і вторинних документів, прикладах провідних ознак та видах вторинних документів.

Як зазначалося вище, первинні джерела містять безпосередні наукові й науково-методичні результати, наукові відомості або нове осмислення відомих ідей і фактів, які є безпосереднім результатом професійної діяльності вченихпрактиків. Вторинні ж документи - це результат “аналітико-синтетичної переробки змісту первинних документів, спрямованої на згортання (стиснення) первинної інформації для зручності використання ії в процесі створення інформаційної продукції. Тож у вторинних документах інформацію, що містилася в одному чи кількох первинних документах, подають скорочено у відомостях про них" [5, 291]. Мета створення вторинних документів полягає в інформуванні дослідників освітянської галузі про потоки і масиви первинних документів (інші документи) 3 актуальних питань розвитку національної і зарубіжної освіти й науки, а також в орієнтації у змісті тієї інформації, яку вони вміщують.

Важливо зазначити, що рівень згортання первинної інформації залежить від інформаційних потреб користувачів та характеризується провідними ознаками вторинних документів [5]. До них належать бібліографічні, реферативні, оглядові й аналітичні документи, що створені як за загальними, так і специфічними ознаками, наприклад, характером інформації, метою складання, читацьким призначенням, видами використаних першоджерел, тематичними межами, наявністю порівнянь і прогнозів, періодичністю підготовки, хронологічними ознаками, структурою, мовою документів, що оглядають $[8,10]$.

Звернемо увагу й на той факт, що сфера застосування вторинної інформації дуже різноманітна - від підготовки матеріалів до семінарських занять, курсових й дипломних робіт до оглядів у статтях, монографіях й дисертаціях, та $\epsilon$ одним із видів діяльності багатьох користувачів: студентів, пошукувачів та аспірантів, науковців і викладачів закладів освіти, фахівців 3 аналітики.

Варіант часткового розв'язання зазначеної мети вбачаємо у наведених нижче вторинних документах науково-інформаційного супроводу освітянської галузі, які представлено в науковоінформаційних ресурсах офіційного вебпорталу ДНПБ України ім. В. О. Сухомлинського.

Важливою складовою зазначених науковоінформаційних документів $є$ випуски довідкового бюлетеня “Аналітичний вісник у сфері освіти й науки" [2]; оглядове видання "Інноваційний розвиток освіти в Україні й зарубіжжі в умовах євроінтеграційних та глобалізаційних процесів" [3]; огляди результатів наукової діяльності установ НАПН України (за матеріалами Загальних зборів НАПН України) [6]; тематичні реферативні огляди 3 актуальних питань розвитку національної та зарубіжної освіти [7]; оперативний моніторинг матеріалів 3МІ освітянського спрямування [4]; низка різних видів бібліографічних посібників.

Для цього за допомогою інформаційних технологій та комп'ютерних засобів достатньо самостійно застосувати пропонований нами алгоритм кількох “кроків”, що охоплює сукупність технічних прийомів у заданій послідовності, а саме: на стартовій сторінці Google (у пошуку) набираємо ДНПБ України ім. В. О. Сухомлинського, після чого відкривається головна сторінка офіційного вебпорталу бібліотеки; у головному меню вебпорталу ДНПБ України ім. В. О. Сухомлинського обираємо рубрику "Ресурси", де розкривається перелік назв розділів; визначаємося з потрібним розділом, у якому подано вторинні документи; обираємо бажану тему, відповідно до якої перед дослідником розкривається зміст необхідного вторинного документа.

Освітньо-пізнавальний процес у цьому разі здійснюватиметься за логікою наукового пошуку, 

ЗАСОБАМИ НАУКОВОЇ БІБЛІОТЕКИ ПЕДАГОГІЧНОГОПРОФІЛЮ

поєднання науково-дослідного й освітнього процесів, концентруватиметься на значенні знань і вмінь студентської молоді при виконанні наукових досліджень. Використання комп’ютерних засобів й інформаційних технологій сприяє розширенню можливостей використання масиву науковоінформаційного матеріалу вторинних документів, яким можуть користуватися студенти в освітньонауковій діяльності.

Таким чином, вторинні науково-інформаційні документи науково-інформаційних ресурсів офіційного вебпорталу ДНПБ України ім. В. О. Сухомлинського як складник джерельної бази наукових досліджень $є$ ефективним інструментом практичного застосування, що розширює спектр науково-інформаційних послуг, оптимізує роботу дослідників освітянської галузі 3 пошуку й практичного використання науковоосвітньої інформації про нові наукові, технічні й методичні досягнення.

На основі аналізу наукових джерел та вивчення педагогічного досвіду науковців-практиків сформульовано висновки: використання розробленого у ДНПБ України ім. В.О. Сухомлинського вторинного документного масиву як комунікаційного інструмента супроводу наукової інформаційноосвітньої діяльності створює оптимальні умови для формування та розвитку у студентської молоді когнітивних вмінь, навичок та мотивації до наукової діяльності.

Перспективи подальших досліджень убачаємо в подальшому здійсненні добору, аналізу та систематизації первинних повнотекстових джерел, які становлять предметне поле дослідження аналітичного супроводу діяльності НАПН України щодо науково-методичного забезпечення модернізації та реформування освітянської галузі, а також оцифрування первинних повнотекстових документів минулої доби, що не втрачають актуальності й нині та становитимуть певний науковий-практичний інтерес для дослідників, практиків освітянської галузі.

\section{ЛIТЕРАТУРА}

1. Агалець, І. О. Професійна діяльність майбутнього освітянина: позиція особистості й мотиваційна їі спрямованість. 3б. наук. пр. Уман. держ. пед. ун-ту ім. Павла Тичини. Умань, 2017. Вип. 1. С. 8-15. Режим доступу: https://library.udpu.edu.ua/library_files/ zbirnuk nayk praz/2017/1/3.pdf. (дата звернення: 05.04.2021).

2. Аналітичний вісник у сфері освіти й науки : довід бюл. Вип. 1-12 / НАПН України, ДНПБ України ім. В. О. Сухомлинського. Київ, 2015-2020. URL: http:// dnpb.gov.ua/ua/періодичні-видання-бібліотеки/13392-2/ (дата звернення: 01.03.2021).

3. Інноваційний розвиток освіти в Україні й зарубіжжі в умовах євроінтеграційних та глобалізаційних процесів : огляд. вид. / НАПН України, ДНПБ України ім. В. О. Сухомлинського ; авт.-упоряд.: Селецький, А. В., Кравченко, С. М., Агалець, І. О. та ін. ; наук. ред. Селецький, А. В. Київ : ДНПБ України ім. В. О. Сухомлинського, 2019. 155 c. URL: https:// dnpb.gov.ua/wp-content/uploads/2019/06/ overview edition 2019.pdf(дата звернення: 01.03.2021).

4. Інформаційно-аналітичний огляд головних подій у сфері освіти, науки й культури, оприлюднених засобами масової інформації України у січні-грудні 2020 / уклад. Т. І. Годецька. Державна науковопедагогічна бібліотека Украӥни імені В. О. Сухомлинського : офіц. портал. URL: https://dnpb.gov.ua/ua/monitorynhzmi/analitychnyy-monitorynh-zmi/ (дата звернення: 10.04.21).

5. Кушнаренко, Н. М., Удалова, В. К. Наукова обробка документів : підручник. 4-те вид., перероб. і доп. Київ : Знання, 2006. 334 с.

6. Огляди результатів наукової діяльності установ НАПН України (за матеріалами Загальних зборів НАПН України) : аналіт. огляди, 2018-2019 рр. / уклад.: А. В. Селецький, Л. А. Рапіна. Державна науковопедагогічна бібліотека Украӥни імені В. О. Сухомлинського : офіц. портал. URL: https://dnpb.gov.ua/ua/iнформаційноаналітичні-ресурси/ (дата звернення: 01.03.2021).

7. Тематичні реферативні огляди : реф. огляди, 2010 2019 / уклад.: I. О. Агалець та ін. Державна науковопедагогічна бібліотека України імені В. О. Сухомлинського : офіц. портал. URL: https:// dnpb.gov.ua/ua/bibliographic-resources-2/ (дата звернення: 01.03.2021).

8. Яценко, О. М. Укладання оглядових документів : практ. посіб. / НАПН України, ДНПБ України ім. В. О. Сухомлинського. Київ : Нілан-ЛТД, 2011. 84 с.

\section{REFERENCES}

1. Ahalets, I. O. (2017). Profesiina diialnist maibutnoho osvitianyna: pozytsiia osobystosti y motyvatsiina yii spriamovanist [Professional activity of the future educator: the position of the personality and its motivational orientation]. Coll. Science. Uman Ave. state ped. University named after Pavlo Tychyna. Available at: https:// library.udpu.edu.ua/library_files/zbirnuk_nayk_praz/2017/ 1/3.pdf(Accessed 05 Apr. 2021) [in Ukrainian].

2. Analitychnyi visnyk u sferi osvity y nauky: dovidkovyi biuleten [Analytical Bulletin in Education and Science: Reference Bulletin]. Issues 1-12. Kyiv. Available at: http://dnpb.gov.ua/ua/періодичні-виданнябібліотеки/13392-2/ [in Ukrainian].

3. Seletskyi, A. V., Kravchenko, S. M. \& Ahalets, I. O. et al (2019). Innovatsiinyi rozvytok osvity v Ukraini y zarubizhzhi $\mathrm{v}$ umovakh yevrointehratsinykh ta hlobalizatsiinykh protsesiv: ohliadove vydannia [Innovative development of education in Ukraine and abroad in the context of European integration and globalization processes: an overview]. Kyiv. Available at: http://dnpb.gov.ua/wp-content/uploads/2019/06/ overview edition 2019.pdf [in Ukrainian].

4. Informatsiino-analitychnyi ohliad holovnykh podii u sferi osvity, nauky y kultury, opryliudnenykh zasobamy 


\section{ВИКОРИСТАННЯ СЕРВІСІВ GООGLЕ У НАВЧАННІ ІНОЗЕМНОЇ МОВИ СТУДЕНТІВ НЕСПЕЦАЛЬНИХФАКУЛЬТЕТІВ}

masovoi informatsii Ukrainy u sichni-hrudni 2020 [An information and analytical review of the main events in the field of education, science and culture, published by the media of Ukraine in January-December 2020]. (Ed.). T. I. Hodetska. Sukhomlynskiy State Scientific and Pedagogical Library of Ukraine. Available at: https:// dnpb.gov.ua/ua/monitorynh-zmi/analitychnyymonitorynh-zmi/ (Accessed10Apr.21) [in Ukrainian].

5. Kushnarenko, N. M. \& Udalova, V. K. (2006). Naukova obrobka dokumentiv : pidruchnyk. 4-te vyd., pererob. i dop. [Scientific processing of documents: a textbook. 4th ed., Reworked. and ext.]. Kyiv, 334 p. [in Ukrainian].

6. Ohliady rezultativ naukovoi diialnosti ustanov NAPN Ukrainy (za materialamy Zahalnykh zboriv NAPN Ukrainy) : analit. ohliady, 2018-2019 rr. [Reviews of the results of scientific activity of the institutions of the National
Academy of Pedagogical Sciences of Ukraine (based on the materials of the General Meeting of the National Academy of Pedagogical Sciences of Ukraine): analyst. reviews, 2018-2019]. (Ed.). A. V. Seletskyi, L. A. Rapina. Sukhomlynskiy State Scientific and Pedagogical Library of Ukraine. Available at: https://dnpb.gov.ua/ua/ informatsiino-analitychni-resursy/ (Accessed 01 Mar. 2021) [in Ukrainian].

7. Tematychni referatyvni ohliady : ref. ohliady, 2010 2019 [Thematic abstracts: ref. reviews, 2010-2019]. (Ed.).I. O. Ahalets et al. Sukhomlynskiy State Scientific and Pedagogical Library of Ukraine. Available at: https:// dnpb.gov.ua/ua/bibliographic-resources-2/ (Accessed 01 Mar. 2021) [in Ukrainian].

8. Yatsenko, O. M. (2011). Ukladannia ohliadovykh dokumentiv: praktychnyi posibnyk [Preparation of survey documents: practical guide]. Kyiv, 84 p. [in Ukrainian].

Стаття надійшла до редакції 02.03.2021

УДК 378.147:004.588

DOI:

Лідія Черчата, кандидат педагогічних наук, доиент кафедри загального і слов'янського мовознавства та іноземних мов Полтавського національного педагогічного університету імені В. Г. Короленка

\section{ВИКОРИСТАННЯ СЕРВICIВ GООGLЕ У НАВЧАННІ IНОЗЕМНОÏ МОВИ СТУДЕНТІВ НЕСПЕЦАЛЬНИХ ФАКУЛЬТЕТІВ}

У статті розглянуто загальні тенденції щуодо иџировізації навчального процесу. Окреслено сфери застосування web-технологій відповідно до иільового призначення. Встановлено, ио сервіси Google володіють широким функиіональним потенціалом у освітній сфері, зокрема, щэодо вивчення іноземної мови студентами неспеціальних факультетів. Охарактеризовано наявні інструменти Google та змодельовано напрями їх застосування.

Ключові слова: презентація; інтерактивні вправи; web-технологї̈; сервіси Google; дистанційне навчання; автоматизація; комунікачійні платформи; інтерфейс.

Puc. 1. Лim. 10.

Lidiia Cherchata, (Ph.D.) Pedagogy, Associate Professor of the General and Slavic Linguistics and Foreign Languages Department Poltava V. G. Korolenko National Pedagogical University

\section{USE OF GOOGLE SERVICES IN FOREIGN LANGUAGE TEACHING OF STUDENTS OF NON-SPECIAL FACULTIES}

The article deals with the general trends in the digitalization of the educational process. The spheres of application of web-technologies according to the purpose are outlined. Services for creation of didactic materials; platforms for communication, cooperation and direct distance learning; demonstration and visualization of material; prompt exchange of data and information; research and retrieval are identified.

It was established that Google services have a wide functional potential in the field of education, in particular, in the study of a foreign language by students of non-special faculties. The existing Google tools are described and the directions of their application are simulated. Special attention is paid to Google Hangouts, Google Talk, Hangouts Meet as platforms for online communication. The opportunities provided by Google Classroom for distance learning of English are revealed. Practical ways to use Google Forms to facilitate and speed up the process of learning the topic are identified. The situations in which the use of Google Sheets and Google Sites is appropriate are simulated. Potential disadvantages of working with Google Translate are emphasized. It is established that the improvement of writing skills should be proportional to the development of English communication skills.

Thematic areas of interaction and Google services that optimize teamwork and accelerate the storage, processing and systematization of results were selected depending on the faculty and specialty of students. The 